\title{
The efficacy of curcumin on PDGF expression and NF-kappa B pathway: TNBS-induced colitis
}

\author{
Yüksel Altınel, M.D.,' ${ }^{1}$ Şenay Yalçın, M.D., ${ }^{2} \odot$ Gülçin Ercan, M.D.,' $\odot$ Erkan Yavuz, M.D.,, \\ Candaş Erçetin, M.D., ${ }^{1}$ ○ Osman Bilgin Gülçiçek, M.D.,' ${ }^{\circ}$ Atilla Çelik, M.D., ${ }^{1}$ \\ (1) Güven Özkaya, M.D., ${ }^{3}$ 이 Hafize Uzun, M.D. ${ }^{4}$
}

\author{
${ }^{1}$ Department of General Surgery, Bağcılar Training and Research Hospital, İstanbul-Turkey \\ 2Department of Pathology, Bağcılar Training and Research Hospital, İstanbul-Turkey \\ ${ }^{3}$ Department of Biostatistics, Uludağ University Faculty of Medicine, Bursa-Turkey \\ ${ }^{4}$ Department of Biochemistry, Cerrahpaşa University Faculty of Medicine, İstanbul-Turkey
}

\begin{abstract}
BACKGROUND: Curcumin is an antioxidant and anti-inflammatory molecule known to be a potent inhibitor of nuclear factor kappa B (NF-kappa B). In this study, we aimed to investigate the therapeutic effects of curcumin on colitis induced by a 2,4,6-trinitrobenzene sulfonic acid (TNBS).
\end{abstract}

METHODS: After the induction of colitis under anesthesia, 42 rats were divided into six groups as follows; the curcumin oral group, curcumin $(20 \mathrm{mg} / \mathrm{kg})$; the corn oil oral group, corn oil $(20 \mathrm{mg} / \mathrm{kg})$ using gastric gavage, the curcumin rectal group, curcumin; the corn oil rectal group, corn oil; the control group, I $\mathrm{mL}$ saline solution $(0.9 \% \mathrm{NaCl})$ were administered using the rectal route. In the sham group, only rectal catheterization was performed. At the end of the seven day, the blood and intestinal tissue samples were obtained for histopathological examination and for MPO, MDA, NO, PDGF, IL-6, TNF-alpha, NF-kappaB.

RESULTS: The macroscopic damage score was significantly higher in curcumin oral, corn oil oral and saline groups when compared to the sham group $(p<0.05)$. The significant differences between groups were evaluated using the biochemical analysis of intestinal tissue for IL-6, NO, NF-KB, PDGF, TNF- $\alpha$, MDA, MPO ( $\mathrm{p}<0.05)$. NF- $\kappa B$ levels of blood in curcumin oral, curcumin rectal, sham, corn oil oral, corn oil rectal groups were significantly increased when compared to saline rectal group $(p \leq 0.00 \mathrm{I})$. NF- $\kappa B$ serum levels of corn oil rectal and control group $(p \leq 0.001)$ were lower than the sham group $(p=0.012)$.

CONCLUSION: The effects of curcumin improved possibly by modulating the NF- $\kappa B$ signaling pathway should be considered against colitis alone or in combination with the conventional anti-colitic therapies in future studies.

Keywords: Anti-inflammatory; anti-oxidant; colitis; curcumin; NF-kappaB.

\section{INTRODUCTION}

Inflammatory Bowel Diseases (IBD), usually referring to UIcerative colitis or Chron's Disease, are determined by increased production of inflammatory cytokines, epithelial cell apoptosis and immune cell infiltration causing to the disruption of intestinal epithelial structure. The intestinal damage of IBD had a growing body of evidence determines that the abnormal production of reactive oxygen species (ROS) and dif- ferentiated antioxidant defense participation. ${ }^{[1,2]}$ Nowadays, various drugs, including mesalamine, sulfasalazine, corticosteroids and immunomodulators, are used to be a part of the treatment of IBD patients. However, there are many side effects of these drugs and complications of diseases that show the unmet needs for the safety of the maintenance therapy. ${ }^{[3,4]}$

Curcumin derived from the root of the turmeric plant (Curcuma longa) appears to be the therapeutic compounds of

Cite this article as: Altınel Y, Yalçın Ş, Ercan G, Yavuz E, Erçetin C, Gülçiçek OB, et al. The efficacy of curcumin on PDGF expression and NF-kappa B pathway: TNBS-induced colitis. Ulus Travma Acil Cerrahi Derg 2020;26:663-670.

Address for correspondence: Yüksel Altınel, M.D.

Bağcılar Eğitim ve Araştırma Hastanesi, Genel Cerrahi Kliniği, İstanbul, Turkey

Tel: +90 212 - 4404000 E-mail: dryukselaltinel@gmail.com

Ulus Travma Acil Cerrahi Derg 2020;26(5):663-670 DOI: 10.14744/tjtes.2019.45570 Submitted: 09.02.2019 Accepted: 01.12.2019 Online: 09.09.2020

Copyright 2020 Turkish Association of Trauma and Emergency Surgery 
pharmacological actions, including anti-tumor, anti-oxidant, anti-proliferative and anti-inflammatory effects. ${ }^{[5,6]}$ Curcumin has an effect on modulating the inhibition of the tumor necrosis factor alfa (TNF- $\alpha$ ) induced nuclear kappa-B (NF-kB) activation pathways. ${ }^{[7,8]}$ Also, it has preventive and therapeutic effects in murine colitis models, including trinitrobenzene sulfonic acid (TNBS)-, dextran sulfate sodium (DSS)-, and dinitrobenzene sulfonic acid (DNB)-induced colitis by inhibiting $\mathrm{NF}-\mathrm{kB} \cdot{ }^{[9,10]}$

The transmural inflammation of colitis induced by trinitrobenzene sulphonic acid (TNBS) affects the intestinal motor apparatus, and subsequently, a loss of myenteric and submucosal neurons adjacent to intestinal smooth muscle cells (ISMC) leading to changes in cell number. ${ }^{[1-14]}$ There are many pluripotent activities of curcumin helping to these effects, such as a potent inhibitor of and platelet-derived growth factor PDGF-stimulated proliferation and pro-inflammatory factors, such as the cytokines IL-I and TNF- $\alpha$ and mesenchymal growth factors, such as insulin-like growth factor (IGF). ${ }^{[15-17]}$ Therefore, we conducted the present study to further approach the inflammation of colonic mucosa and investigate the possible preventive and therapeutic effects of curcumin considering new alternative therapy. Especially, we investigated the efficacy of different methods like the oral or rectal route of the curcumin treatment in this experimental model through the pathways of myeloperoxidase (MPO) activity and lipid peroxidation malondialdehyde (MDA).

\section{MATERIALS AND METHODS}

\section{Animals}

Forty-two female Wistar Hannover rats weighing 300 to 500 $g$ were used in this study. The animals were kept in a restricted access room with controlled temperature and light cycle. The animals were fed on standard rat chow, allowed access to tap water ad libitum. The rats were housed in individual standard cages. The study protocol was in accordance with the guidelines for animal research and approved by the Animal Ethical and Research Committee of Bagcilar Research and Training Hospital.

\section{Reagents}

The trinitro-benzene sulfonic acid (TNBS) (5\% w/v, $40 \mathrm{mg}$ ) and Curcumin were purchased from Sigma Chemical Co., St. Louis, USA. Other agents used in this study were all of the analytical grades.

\section{Experimental Protocol}

On the day of induction, the mixture of $0.6 \mathrm{~mL}$ of TNBS and $0.25 \mathrm{~mL}$ of $50 \%$ ethanol was instilled into the lumen of the colon by $6 \mathrm{~F}$ feeding tube, which was inserted rectally until the tip was $8 \mathrm{~cm}$ proximal to the anus. Then, $0.5 \mathrm{~mL}$ of air was given to ensure that the whole mixture was instilled into the lumen of the colon.
There were six groups consisting of seven rats for each: (I) control group: rats were treated with daily rectal single dose of saline $(\mathrm{l} \mathrm{mL}, 0.9 \% \mathrm{NaCl})$ using feeding tube from day one to day 7; (2) oral curcumin group: rats were treated with daily single dose of curcumin $(20 \mathrm{mg} / \mathrm{kg})$ which was dissolved in corn oil ( $1 \mathrm{mg} / \mathrm{mL}$ ) by gastric gavage for seven days following the induction of colitis; (3) rectal curcumin group: rats were treated with daily rectal single dose of curcumin $(20 \mathrm{mg} / \mathrm{kg})$ which was dissolved in corn oil $(1 \mathrm{mg} / \mathrm{mL})$ by feeding tube for seven days following the induction of colitis; (4) sham group: no colitis was induced, only rectal insertion of feeding tube was performed once a day from day I to day 7; (5) oral corn oil group: rats were treated with daily single dose of corn oil (20 $\mathrm{mg} / \mathrm{kg}$ ) by gastric gavage for seven days following the induction of colitis; (6) rectal corn oil group: rats were treated with daily rectal single dose of corn oil $(20 \mathrm{mg} / \mathrm{kg})$ by feeding tube for seven days following the induction of colitis. At postoperative 7th day, after their weight measurements, finally, all rats under general anesthetized with intramuscular ketamine $(50 \mathrm{mg} /$ $\mathrm{kg}$; Ketalar, Pfizer Inc.) and xylazine (10 mg/kg, Ronpum, Bayer AG), were performed laparotomy and total colectomy after inspection for adhesions and were sacrificed by an intra-cardiac puncture to get blood samples for nuclear kappa-B (NF-kB), nitric oxide (NO), platelet-derived growth factor (PDGF), interleukin 6 (IL-6), tumor necrosis factor alfa (TNF- $\alpha$ ).

When tissue samples were obtained, macroscopic damage was scored on a scale of 0 to 13 modified from a description by Wang et al. ${ }^{[18]}$ (Table I) by the same pathologist who was

Table I. Macroscopic scoring of mucosal damage in colitis

\begin{tabular}{lc}
\hline Macroscopic damage & Score \\
\hline Ulceration and inflammation & 0 \\
None & I \\
Local hyperemia, no ulcer & 2 \\
One site of ulcer not accompanied by congestion & \\
or thickening of the intestinal wall & 3 \\
One site of ulcer accompanied by inflammation & 4 \\
$\geq 2$ sites of ulcer accompanied by inflammation & 5 \\
I cm > inflamed segment + ulcer site $\geq 2$ & 6 \\
I cm < inflamed segment + ulcer site $\geq 2$ & $7-10$ \\
2 cm $\leq$ inflamed segment (the score increases & \\
I with each I cm enlargement of the inflamed & \\
segment) & \\
Adhesions & 0 \\
None & 1 \\
Mild (easy to separate colon from other tissues) & 2 \\
Severe & \\
Diarrhea & \\
None & \\
Present & \\
\hline &
\end{tabular}


blinded to the group assignment of the rats. Later, the tissue samples were fixed with $10 \%$ formaldehyde solution. Tissue samples of $5 \mathrm{~mm}$ in length were taken from $8 \mathrm{~cm}$ distal segments of total colectomy specimens. All samples were embedded in paraffin wax, and sections were taken and stained with hematoxylin-eosin ( $\mathrm{HE})$. All sections were evaluated using light microscopy and scored on a scale of 0 to 10 , as described by Wang et al. ${ }^{\left[{ }^{[8]}\right.}$ (Table 2 ) in a blinded fashion by the same pathologist.

Serum IL-6, TNF- $\alpha$ levels nuclear kappa-B (NF-Kb), nitric oxide (NO) and platelet-derived growth factor (PDGF) were analyzed with ELISA using rat kits (InvitrogenTM Rat Immunoassay Kit; Invitrogen Corporation, Carlsbad, California, USA).

\section{Myeloperoxidase Activity Assay}

Myeloperoxidase (MPO) is a biochemical sample of neutrophil infiltration into intestinal tissues and was used to determine colitis. Tissue samples were homogenized in 10 volumes of ice-cold potassium phosphate buffer $(50 \mathrm{Mm} \mathrm{K2HPO} 4, \mathrm{pH}$ 6.0) containing hexadecyltrimethylammonium bromide $(0.5 \%$, $\mathrm{g} / \mathrm{mL}$ ). One unit of the enzyme activity was established as the amount of MPO present per gram of tissue weight that causes a change in absorbance of $10 \mathrm{~min}$ at $460 \mathrm{~nm}\left(37^{\circ} \mathrm{C}\right)$. The MPO activity in the supernatant was evaluated by the assay kit, depending on its provider's instructions.

Table 2. Microscopic scoring of colitis

\begin{tabular}{|c|c|}
\hline Histological lesion & Score \\
\hline \multicolumn{2}{|l|}{ Ulcer } \\
\hline None & 0 \\
\hline Ulcer $<3$ mm & 1 \\
\hline Ulcer $>3 \mathrm{~mm}$ & 2 \\
\hline \multicolumn{2}{|l|}{ Inflammation } \\
\hline None & 0 \\
\hline Mild & 1 \\
\hline Severe & 2 \\
\hline \multicolumn{2}{|l|}{ Granuloma } \\
\hline None & 0 \\
\hline Present & I \\
\hline \multicolumn{2}{|l|}{ Depth of the disease } \\
\hline None & 0 \\
\hline Submucosal layer & 1 \\
\hline Muscular layer & 2 \\
\hline Serosal layer & 3 \\
\hline \multicolumn{2}{|l|}{ Fibrosis } \\
\hline None & 0 \\
\hline Mild & 1 \\
\hline Severe & 2 \\
\hline
\end{tabular}

\section{Lipid Peroxidation Determination}

The colonic tissue for the determination of MDA and NO substances were homogenized in-cold PBS $(\mathrm{pH} 7.4)$ and centrifuged at $3000 \mathrm{rpm}$ for $10 \mathrm{~min}$ at $4^{\circ} \mathrm{C}$. The last supernatant was collected at $20^{\circ} \mathrm{C}$ until analysis with corresponding assay kits according to the manufacturer's guide. The colon tissue samples were homogenized in $10 \% \mathrm{KCl}(1.10 \mathrm{~g} / \mathrm{mL})$ in a glass-glass homogenizer. Homogenate was added into the mixture, which consisted of $8.1 \%$ sodium dodecyl sulfate, $0.82 \%$ thiobarbituric acid, and acetate buffer $(3 \mathrm{M}, \mathrm{pH} 3.5)$, and the reaction was evaluated at $532 \mathrm{~nm}$ by the spectrophotometer. Results were identified as $\mu \mathrm{mol} / \mathrm{L}$ using a standard curve.

\section{Statistical Analysis}

Data were expressed as means \pm standard error of the mean (SEM). Statistical analyses were performed using the Statistical Package for Social Sciences version 10.0I(SPSS, Chicago, IL, USA). Overall comparisons between the groups were made using I-way analyses of variance (ANOVA). The Kruskal-Wallis test followed by the Mann-Whitney $U$ test was used for statistical evaluation, and $p<0.05$ was accepted as a level of significance.

\section{RESULTS}

There were no statistically significant differences in weight loss between all groups. Also, when we evaluated the intra-abdominal adhesion, there were no statistically significant differences among the groups.

\section{Biochemical Assessment}

The biochemical analysis of blood samples for PDGF, TNF- $\alpha$, MPO did not show any significant difference among groups (Table 3). NF-kB levels of blood in curcumin oral, curcumin rectal, sham, corn oil oral, corn oil rectal groups were significantly increased when compared to saline rectal group $(p \leq 0.00 \mathrm{l})$. NF-kB serum levels of corn oil rectal and control group $(p \leq 0.00 I)$ were lower than the sham group $(p=0.012)$. The significant differences between groups were evaluated by the analysis of intestinal tissue sampling for IL-6, NO, NF-kB, PDGF, TNF- $\alpha$, MDA, MPO ( $p<0.05)$ (Table 4).

Tissue NF-kB level of curcumin oral group was lower than curcumin rectal $(p \leq 0.00 I)$, sham $(p \leq 0.00 I)$ and corn oil oral groups $(p=0.030)$. Tissue NF-kB level of curcumin rectal group was higher than saline rectal $(p=0.005)$, curcumin oral $(p \leq 0.00 \mathrm{I})$ and corn oil rectal $(p=0.045)$ groups. The sham group for tissue NF-kB level was higher than saline rectal $(p \leq 0.00 \mathrm{I})$, curcumin oral $(p \leq 0.00 \mathrm{I})$, corn oil oral $(p=0.037)$ and corn oil rectal $(p \leq 0.00 I)$ groups.

The tissue level of PDGF of the sham group was higher than the saline rectal $(p=0.003)$, curcumin oral $(p \leq 0.001)$, corn oil oral $(p=0.004)$ and corn oil rectal $(p \leq 0.001)$ groups. The 
tissue level of PDGF in the curcumin oral group was significantly lower when compared to the curcumin rectal group $(p=0.048)$.

\section{Pro-Inflammatory Cytokine Release}

IL-6 serum levels in corn oil oral group were significantly increased when compared to corn oil rectal $(p=0.033)$ and saline rectal $(p=0.035)$ groups. IL-6 tissue level of the sham group was significantly higher than all other groups $(p<0.05)$. TNF- $\alpha$ tissue level of the corn oil oral group was higher than the saline rectal $(p=0.020)$ and corn oil rectal $(p=0.033)$ groups. The TNF- $\alpha$ tissue level of the curcumin oral group was lower than the curcumin rectal $(p=0.00 \mathrm{I})$ and sham $(p=0.004)$ groups. The TNF- $\alpha$ tissue level in the curcumin rectal group was higher when comparing to the saline rectal $(p \leq 0.00 I)$, curcumin oral $(p \leq 0.00 \mathrm{I})$ and corn oil rectal $(p \leq 0.001)$. The TNF- $\alpha$ tissue level of the sham group was higher than the saline rectal $(p \leq 0.001)$, curcumin oral $(p=0.004)$ and corn oil rectal $(p \leq 0.00 I)$.

\section{The Inflammatory Response}

MPO tissue level of the sham group was significantly higher than the saline rectal $(p=0.033)$ and curcumin oral $(p=0.005)$ groups.

\section{Colonic Oxidative Differentiation}

MDA serum level of the saline rectal group was lower than the sham group $(p=0.017)$, curcumin rectal $(p=0.015)$ and corn oil oral group $(p=0.010)$. MDA tissue level of the sham group was significantly higher than the curcumin oral group $(p=0.0 \mid 3)$.

NO serum level of the curcumin oral group was significantly higher than the saline rectal group $(p=0.037)$.

NO tissue level of the sham group was higher than curcumin oral $(p=0.002)$ and corn oil rectal $(p=0.038)$ groups.

\section{Histopathological Findings (Table 5)}

The macroscopic damage score was significantly higher in curcumin oral $(p=0.016)$, corn oil oral $(p=0.016)$ and saline rectal $(p=0.006)$ groups when compared to the sham group. However, no significant difference was found between curcumin and corn oil groups. Even if it was not statistically significant, the macroscopic and microscopic damage scores of the curcumin rectal group were more decreased than the curcumin and corn oil groups except the sham group (Fig. I). Microscopic damage score was significantly higher in curcumin oral $(p=0.02)$, saline rectal $(p=0.015)$ and corn oil oral $(p=0.019)$

Table 3. The biochemical analysis of blood samples (mean-standard deviation)

\begin{tabular}{|c|c|c|c|c|c|c|c|}
\hline Biochemical & s_IL6 & s_NO & s_NFkB & s_PDGF & s_TNF- $\alpha$ & s_MDA & s_MPO \\
\hline Saline rectal & $|56.74 \pm 2| .40$ & $72.66 \pm 22.94$ & $1.50 \pm 0.46$ & $2.52 \pm 0.28$ & $143.92 \pm 55.19$ & $1.27 \pm 0.09$ & $19.81 \pm 1.82$ \\
\hline Curcumin oral & $164.57 \pm 19.16$ & $105.49 \pm 28.92$ & $3.9 I \pm 0.71$ & $2.62 \pm 0.79$ & $186.39 \pm 39.68$ & $1.63 \pm 0.27$ & $20.36 \pm 2.51$ \\
\hline Curcumin rectal & $187.61 \pm 19.45$ & $97.24 \pm 17.10$ & $3.83 \pm 0.51$ & $2.98 \pm 0.40$ & $174.53 \pm 39.74$ & $1.70 \pm 0.24$ & $21.25 \pm 3.17$ \\
\hline Sham & $165.70 \pm 31.86$ & $97.98 \pm 12.66$ & $4.32 \pm 0.56$ & $2.7 I \pm 0.3 I$ & $193.81 \pm 18.52$ & $1.69 \pm 0.27$ & $22.73 \pm 2.85$ \\
\hline Corn oil oral & $206.60 \pm 51.05$ & $90.91 \pm 9.83$ & $3.93 \pm 0.39$ & $2.91 \pm 0.66$ & $191.89 \pm 20.90$ & $1.72 \pm 0.19$ & $23.01 \pm 1.93$ \\
\hline Corn rectal & $156.28 \pm 20.33$ & $80.89 \pm 19.62$ & $3.32 \pm 0.43$ & $3.08 \pm 0.65$ & $181.65 \pm 37.00$ & $1.45 \pm 0.22$ & $20.33 \pm 3.00$ \\
\hline $\mathrm{P}^{*}$ & 0.017 & 0.036 & $<0.001$ & 0.364 & 0.158 & 0.004 & 0.126 \\
\hline
\end{tabular}

IL-6, NO, NF-kB, PDGF, MPO, MDA: ( $\mu$ M/l), TNF- $\alpha$ (pg/ml). Data are means $\pm S E M . *: ~ p<0.05$, statistically significant. IL6: Interleukin 6; NO: Nitric oxide; NFkB: Nuclear kappa-B; PDGF: Platelet-derived growth factor; TNF-a: Tumor necrosis factor alfa; MDA: Malondialdehyde; MPO: Myeloperoxidase.

Table 4. The analysis of intestinal tissue sampling (mean-standard deviation), (pg/g tissue)

\begin{tabular}{lccccccc}
\hline Tissue & t_IL6 & t_NO & t_NFkB & t_PDGF & t_TNF- $\alpha$ & t_MDA & t_MPO \\
\hline Saline rectal & $130.88 \pm 61.79$ & $55.68 \pm 5.33$ & $1.83 \pm 0.68$ & $1.83 \pm 0.95$ & $99.56 \pm 33.21$ & $1.11 \pm 0.51$ & $12.55 \pm 5.67$ \\
Curcumin oral & $98.48 \pm 56.79$ & $33.24 \pm I 1.09$ & $1.50 \pm 0.39$ & $1.20 \pm 0.66$ & $129.53 \pm 39.46$ & $0.94 \pm 0.43$ & $10.51 \pm 4.62$ \\
Curcumin rectal & $197.74 \pm 53.88$ & $60.33 \pm 27.19$ & $3.22 \pm 1.11$ & $2.92 \pm 0.55$ & $243.54 \pm 92.06$ & $1.55 \pm 0.22$ & $18.64 \pm 5.85$ \\
Sham & $339.09 \pm 122.03$ & $71.59 \pm 17.63$ & $3.77 \pm 0.69$ & $4.14 \pm 2.18$ & $234.36 \pm 47.89$ & $1.88 \pm 0.92$ & $21.43 \pm 2.83$ \\
Corn oil oral & $203.5 I \pm 43.02$ & $51.65 \pm 13.36$ & $2.65 \pm 0.32$ & $1.85 \pm 0.59$ & $188.44 \pm 28.55$ & $1.31 \pm 0.28$ & $14.12 \pm 1.22$ \\
Corn rectal & $124.11 \pm 19.59$ & $43.49 \pm 17.99$ & $2.13 \pm 0.45$ & $1.41 \pm 0.10$ & $104.82 \pm 17.44$ & $1.11 \pm 0.19$ & $18.12 \pm 8.18$ \\
P* & $<0.001$ & 0.003 & $<0.001$ & $<0.001$ & $<0.001$ & 0.013 & 0.003 \\
\hline
\end{tabular}

*: $\mathrm{p}<0.05$, statistically significant. IL6: Interleukin 6; NO: Nitric oxide; NFkB: Nuclear kappa-B; PDGF: Platelet-derived growth factor; TNF-a: Tumor necrosis factor alfa MDA: Malondialdehyde; MPO: Myeloperoxidase. 
Table 5. The histopathological comparison of groups, mean (min-max)

\begin{tabular}{lcccccc}
\hline Histopathological & $\begin{array}{c}\text { Macroscopic } \\
\text { damage score }\end{array}$ & $\begin{array}{c}\text { Microscopic } \\
\text { damage score }\end{array}$ & $\begin{array}{c}\text { Inflammatory } \\
\text { cell infiltration }\end{array}$ & $\begin{array}{c}\text { Crypt } \\
\text { abscess }\end{array}$ & Ulcer & Granuloma \\
\hline Saline rectal & $3(2-4)$ & $8(4-9)$ & $3(2-3)$ & $I(0-2)$ & $2(I-2)$ & $2(I-2)$ \\
Curcumin oral & $2(I-4)$ & $7(4-9)$ & $3(2-3)$ & $I(0-2)$ & $2(I-2)$ & $2(I-2)$ \\
Curcumin rectal & $I(0-3)$ & $I(0-9)$ & $I(0-3)$ & $0(0-3)$ & $0(0-2)$ & $I(0-2)$ \\
Sham & $0(0-I)$ & $0(0-9)$ & $0(0-2)$ & $0(0-0)$ & $0(0-0)$ & $0(0-0)$ \\
Corn oil & $3(I-4)$ & $8(3-9)$ & $3(I-3)$ & $2(0-3)$ & $2(0-2)$ & $2(0-2)$ \\
Corn rectal & $2(I-4)$ & $4(3-9)$ & $2(I-3)$ & $I(0-3)$ & $0(0-2)$ & $5(0-2)$ \\
P* & $0.00 I$ & 0.003 & 0.003 & 0.105 & 0.005 & 0.006 \\
\hline$*:$ p $<0.05$, statistically significant. & & & & &
\end{tabular}

groups than the sham group. The inflammatory cell accumulation and ulceration were significantly higher in the curcumin oral group than the sham group $(p=0.019 / p=0.009)$ (Fig. 2). Furthermore, the corn oil oral and saline rectal groups' inflammatory cell accumulation was significantly higher than the

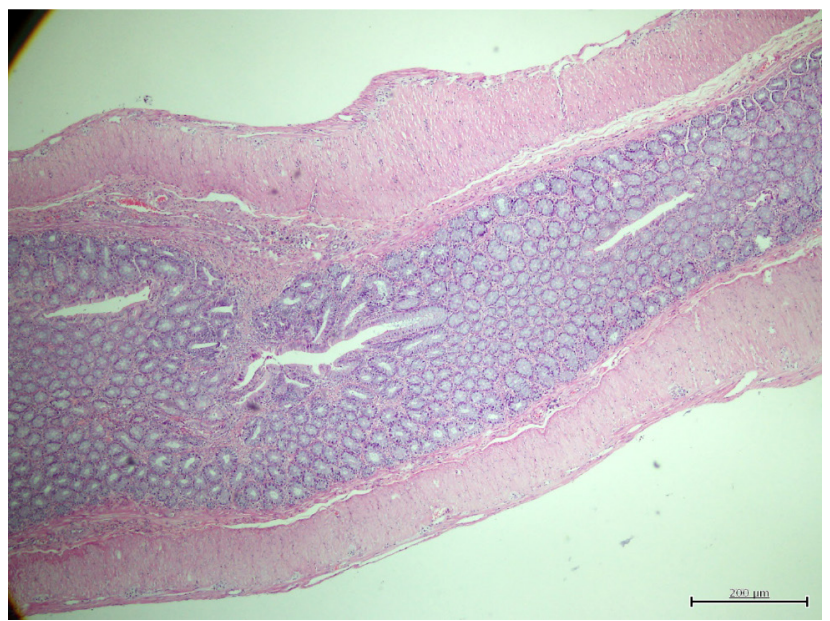

Figure 1. The rectal curcumin administration; normal intestinal tissue (HEx4).

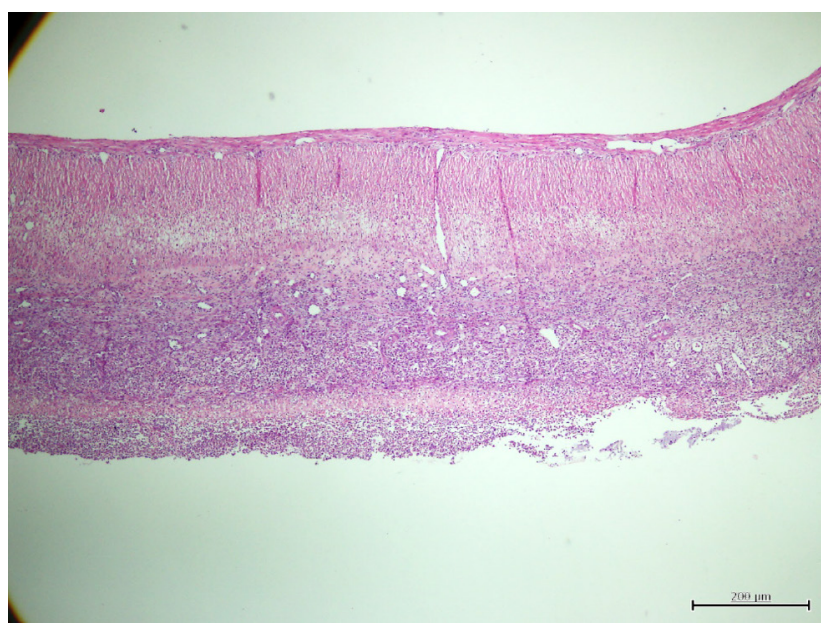

Figure 2. The administration of oral curcumin; the area of ulcer (HEx4). sham group $(p=0.03 \mathrm{I} / \mathrm{p}=0.0 \mathrm{II})$. However, there was no statistical significance. The inflammatory cell, ulcer and granuloma formation of the curcumin rectal group had slightly decreased levels comparing to the corn oil and curcumin groups except for the sham group. Granuloma formation of saline rectal $(p=0.049)$ and curcumin oral $(p=0.008)$ group was significantly higher than the sham group. In addition to that, the mucosal disruption of the sham group was significantly lower than the curcumin oral $(p=0.04)$ and saline rectal $(p=0.004)$ groups.

\section{DISCUSSION}

This study aims to investigate the efficacy of different treatment methods like oral or rectal routes of the curcumin medication for IBD model. The TNBS colitis had granulomas with infiltration of inflammatory cells over the intestinal layers. Similar to our study, the saline rectal group has more than other groups. Although there are various reagents (such as DSS, and acetic acid) to contribute the colitis experiments, TNBS has the useful potential in the clinic for the management of the human diseases. ${ }^{[19-21]}$ The outcomes of curcumin on chemically induced colitis experiments have been precisely determined in the literature. However, it is not established yet, which therapy regimen (oral or rectal) is efficient for the treatment modalities of colitis. The initiation and maintenance of inflammation in IBD have been established by NO overproduction and upregulation of inducible nitric oxide synthase (iNOS). Furthermore, the Nuclear kappa-B (NF-kB) has been primarily activated by oxidative stress. Additionally, TNF- $\alpha$ has a potential initiation for NF-kB in monocytes and then, IL-6 is expressed by the regulation of NF-kB. ${ }^{[22]}$

The anti-inflammatory effects of curcumin are predominantly expressed by the inhibition of the pathways and mediators, such as NF-kB and TNF- $\alpha$ initiated oxidative stress. The treatment of curcumin has beneficial effects on decreasing the level of NO and MDA in the colonic mucosa. ${ }^{[22,23]}$ According to our findings, we had similar outcomes in curcumin oral group when comparing to other groups for the levels of MPO, MDA, NO, IL-6, TNF- $\alpha$, NF-kB. However, there was a dilemma; it was not statistically significant, but the macro- 
scopic and microscopic damage scores of the curcumin rectal group decreased more than the curcumin oral and corn oil groups. Although the decrease of IL-6 in the curcumin oral group was higher than the curcumin rectal group, the microscopic damage score suggesting that topical-rectal administration of curcumin might have some more beneficial effects on anti-inflammatory efficiency.

The severity of the inflammatory injuries has been evaluated by morphological injury and histological variations. One of the markers of the acute inflammatory response is MPO that accomplishes the activity of neutrophils. The elevated MPO levels of the acetic acid-induced colitis were reduced by the treatment of curcumin correlated with the histopathological findings, such as inflammatory cell infiltration. ${ }^{[2,24,25]}$ However, we had discordance in the histopathological and the colon samples for MPO levels when comparing oral and rectal routes of curcumin treatment. The scores of histopathological findings were lower in curcumin rectal; on the other hand, the tissue samples were lower in the curcumin oral rectal groups when comparing MPO. Additionally, our oral curcumin therapy group MPO results were concordant with the findings of enema containing study by Kadri and et al. ${ }^{[26]}$ Maybe the longer study periods are needed to evaluate the different types of administration of curcumin therapies or scoring systems for the pathological findings.

MDA is a good indicator of the oxidative stress and the lipid peroxidation process. The colonic MDA is in the increasing range of both human and animal models for ulcerative colitis, similar to our current study results. ${ }^{[24]}$ Moreover, we evaluated the treatment of curcumin, causing the reduction of MDA levels in the rats with colitis like other studies. This conclusion could be one of the results of the reduction in neutrophil infiltration by curcumin effects in the colonic samples. ${ }^{[2,10]}$

The anti-inflammatory effects of curcumin have an influence on the treatment of colitis related to the inhibition of NF-kB pathways and its antioxidant contents. The cellular signaling pathways induced apoptosis are containing the $\mathrm{Bcl}-2$ family of proto-oncogenes, transcription factor NF-kB and TNF- $\alpha$. [2] There is a study related to ROS-induced cytotoxicity, including the oxidants and epithelial apoptosis by inhibiting the neutrophil and macrophages in the TNF- $\alpha$ colitis model. ${ }^{[27]}$ Controversially, in our study, it was not exactly well-matched with these findings. The tissue NF-kB and TNF- $\alpha$ levels of the curcumin oral group was lower than other groups, and it was not statistically significant. However, the histopathological correlation was observed by the curcumin rectal group. Unlike some studies, ${ }^{[2,27]}$ we had a deficiency to succeed at the finding of the epithelial cell apoptosis by $\mathrm{Bcl}-2$ immunohistochemical dye in which there was no meaningful evaluation performed by our pathologist to mention.

During inflammatory reactions, some of the reactive oxygen species (ROS) production generated when PDGF binds to its receptor and oxidized a cysteine residue in the active site of phosphates following the transduction of PDGF-signaling. ${ }^{28]}$ The phosphatase inhibition and reduction of PDGF signaling occurred as a result of anti-oxidant effects. ${ }^{[29]}$ Due to the antioxidant properties of curcumin, the PDGF stimulated ROS generation in cultured VSMC was inhibited by the effects of both curcumin and bisdemethoxy curcumin that was the differential effects of these compounds on PDGF-signaling. ${ }^{[28,29]}$ When we concerned about the similar pathways, the biochemical findings that we obtained from our experiment, was correlated with the literature. The amount of PDGF for the curcumin oral group was I.20 \pm 0.66 (mean-standard error) lower than the other groups. However, histopathologically, the curcumin rectal group showed more improvement among the inflammatory changes considering the influence of the anti-oxidant effects of curcumin. Furthermore, it was reported that curcumin has some analogs and nano-formulations properties for potentialenhancement of their therapeutic administrations. ${ }^{[22]}$ That could be considered as a beneficial point for further improvements of any doses and routes in curcumin treatments like our study. Despite its various alterations in results of experimental studies, there is a wide range of clinical applications of curcumin in some case series and small clinical trials for every stage of IBD follow up, such as Hanai et al. ${ }^{[8,22]}$ In the study of Hanai et al.., ${ }^{[8]}$ they had safe and effective clinical conclusions of the curcumin treatment for ulcerative colitis patients, besides its undetermined dosages and combined components of medication for curcumin administration. Especially, that is the primary start point of view of our study to figure out the different dosages and the application routes comparing the literature.

In conclusion, the results of this study suggest that substantially the curcumin may be considered to improve the histopathological findings on the rectal route and the biochemical antioxidant and anti-inflammatory assessments of the oral route. Although we did not perform both types of administration and additionally different doses compared to literature, there were no exact solutions determined mainly for clinical usage. As far as we concerned, further research with different doses may be beneficial to undertake the therapeutic components of curcumin into clinical use.

\section{Acknowledgments}

This study was presented as a poster at the 2016 ASCRS Annual Scientific Meeting in Los Angeles, CA.

\section{Funding}

This study was supported by the Research Fund of Bagcilar Research and Training Hospital. The authors received no financial support for the authorship and publication of this article.

Ethics Committee Approval: Approved by the local ethics committee. 
Peer-review: Internally peer-reviewed.

Authorship Contributions: Concept: Y.A.; Design: Y.A., H.U.; Supervision: H.U.; Fundings: G.E., E.Y.; Materials: O.B.G., A.Ç.; Data: Y.A., Ş.Y.; Analysis: G.Ö.; Literature search: Y.A., C.E.; Writing: Y.A.; Critical revision: Y.A., H.U.

Conflict of Interest: None declared.

Financial Disclosure: The authors declared that this study has received no financial support.

Funding: This study was supported by the Research Fund of Bagcilar Training and Research Hospital.

\section{REFERENCES}

1. Sartor RB. Mucosal immunology and mechanisms of gastrointestinal inflammation. In: Sleisenger and Fordtran's Gastrointestinal and Liver Disease. Feldman M, Friedman LS, Brandt LJ, editors. Philadelphia, PA: WB Saunders; 2002. pp.21-51.

2. Topcu-Tarladacalisir Y, Akpolat M, Uz YH, Kizilay G, Sapmaz-Metin M, Cerkezkayabekir A, et al. Effects of curcumin on apoptosis and oxidoinflammatory regulation in a rat model of acetic acid-induced colitis: the roles of $\mathrm{c}$-Jun $\mathrm{N}$-terminal kinase and $\mathrm{p} 38$ mitogen-activated protein kinase. J Med Food 2013;16:296-305. [CrossRef]

3. Hanauer SB. Medical therapy for ulcerative colitis 2004. Gastroenterology 2004;126:1582-92. [CrossRef]

4. Hanauer SB. Inflammatory bowel disease: epidemiology, pathogenesis, and therapeutic opportunities. Inflamm Bowel Dis 2006;12:S3-9. [CrossRef]

5. Calabrese V, Butterfield DA, Stella AM. Nutritional antioxidants and the heme oxygenase pathway of stress tolerance: novel targets for neuroprotection in Alzheimer's disease. Ital J Biochem 2003;52:177-81.

6. Duvoix A, Blasius R, Delhalle S, Schnekenburger M, Morceau F, Henry E, et al. Chemopreventive and therapeutic effects of curcumin. Cancer Lett 2005;223:181-90. [CrossRef]

7. Aggarwal S, Ichikawa H, Takada Y, Sandur SK, Shishodia S, Aggarwal BB. Curcumin (diferuloylmethane) down-regulates expression of cell proliferation and antiapoptotic and metastatic gene products through suppression of IkappaBalpha kinase and Akt activation. Mol Pharmacol 2006;69:195-206. [CrossRef]

8. Hanai H, Iida T, Takeuchi K, Watanabe F, Maruyama Y, Andoh A, et al. Curcumin maintenance therapy for ulcerative colitis: randomized, multicenter, double-blind, placebo-controlled trial. Clin Gastroenterol Hepatol 2006;4:1502-6. [CrossRef]

9. Jian YT, Mai GF, Wang JD, Zhang YL, Luo RC, Fang YX. Preventive and therapeutic effects of NF-kappaB inhibitor curcumin in rats colitis induced by trinitrobenzene sulfonic acid. World J Gastroenterol 2005;11:1747-52. [CrossRef]

10. Deguchi Y, Andoh A, Inatomi O, Yagi Y, Bamba S, Araki Y, et al. Curcumin prevents the development of dextran sulfate Sodium (DSS)-induced experimental colitis. Dig Dis Sci 2007;52:2993-8. [CrossRef]

11. Sanovic S, Lamb DP, Blennerhassett MG. Damage to the enteric nervous system in experimental colitis. Am J Pathol 1999;155:1051-7. [CrossRef]

12. Lourenssen S, Wells RW, Blennerhassett MG. Differential responses of intrinsic and extrinsic innervation of smooth muscle cells in rat colitis. Exp Neurol 2005;195:497-507. [CrossRef]
13. Marlow SL, Blennerhassett MG. Deficient innervation characterizes intestinal strictures in a rat model of colitis. Exp Mol Pathol 2006; 80:5466. [CrossRef]

14. Flynn RS, Murthy KS, Grider JR, Kellum JM, Kuemmerle JF. Endogenous IGF-I and alphaVbeta3 integrin ligands regulate increased smooth muscle hyperplasia in stricturing Crohn's disease. Gastroenterology 2010;138:285-93. [CrossRef]

15. Nair DG, Miller KG, Lourenssen SR, Blennerhassett MG. Inflammatory cytokines promote growth of intestinal smooth muscle cells by induced expression of PDGF-R $\beta$. J Cell Mol Med 2014;18:444-54. [CrossRef]

16. Hua Y, Dolence J, Ramanan S, Ren J, Nair S. Bisdemethoxycurcumin inhibits PDGF-induced vascular smooth muscle cell motility and proliferation. Mol Nutr Food Res 2013;57:1611-8. [CrossRef]

17. Yang X, Thomas DP, Zhang X, Culver BW, Alexander BM, Murdoch WJ, et al. Curcumin inhibits platelet-derived growth factor-stimulated vascular smooth muscle cell function and injury-induced neointima formation. Arterioscler Thromb Vasc Biol 2006;26:85-90. [CrossRef]

18. Wang H, Ouyang Q, Hu RW. Establishment of a trinitrobenzene sulfonic acid-induced rat colitis model. Chin J Gastroenterol 2001;6:7-10.

19. Jurjus AR, Khoury NN, Reimund JM. Animal models of inflammatory bowel disease. J Pharmacol Toxicol Methods 2004;50:81-92. [CrossRef]

20. Dong WG, Liu SP, Yu BP, Wu DF, Luo HS, Yu JP. Ameliorative effects of sodium ferulate on experimental colitis and their mechanisms in rats. World J Gastroenterol 2003;9:2533-8. [CrossRef]

21. Vicario M, Crespí M, Franch À, Amat C, Pelegrí C, Moretó M. Induction of Colitis in Young Rats by Dextran Sulfate Sodium. Dig Dis Sci 2005;50:143-50. [CrossRef]

22. Sreedhar R, Arumugam S, Thandavarayan RA, Karuppagounder V, Watanabe $\mathrm{K}$. Curcumin as a therapeutic agent in the chemoprevention of inflammatory bowel disease. Drug Discov Today 2016;21:843-9. [CrossRef]

23. Midura-Kiela MT, Radhakrishnan VM, Larmonier CB, Laubitz D, Ghishan FK, Kiela PR. Curcumin inhibits interferon- $\gamma$ signaling in colonic epithelial cells. Am J Physiol Gastrointest Liver Physiol 2012;302:G8596. [CrossRef]

24. El-Abhar HS, Hammad LN, Gawad HS. Modulating effect of ginger extract on rats with ulcerative colitis. J Ethnopharmacol 2008;118:367-72.

25. Ung VY, Foshaug RR, MacFarlane SM, Churchill TA, Doyle JS, Sydora $\mathrm{BC}$, et al. Oral administration of curcumin emulsified in carboxymethyl cellulose has a potent anti-inflammatory effect in the IL-10 gene-deficient mouse model of IBD. Dig Dis Sci 2010;55:1272-7. [CrossRef]

26. Kadri CJ, Pereira JA, Campos FG, Ortega MM, Bragion CB, Martinez CA. Anti-inflammatory effects of enemas containing an oily extract of curcumin in an experimental model of diversion colitis. Histol Histopathol 2017;32:161-9.

27. Mouzaoui S, Rahim I, Djerdjouri B. Aminoguanidine and curcumin attenuated tumor necrosis factor (TNF)- $\alpha$-induced oxidative stress, colitis and hepatotoxicity in mice. Int Immunopharmacol 2012;12:302-11.

28. Rhee SG, Kang SW, Jeong W, Chang TS, Yang KS, Woo HA. Intracellular messenger function of hydrogen peroxide and its regulation by peroxiredoxins. Curr Opin Cell Biol 2005;17:183-9. [CrossRef]

29. Kappert K, Sparwel J, Sandin A, Seiler A, Siebolts U, Leppänen O, et al. Antioxidants relieve phosphatase inhibition and reduce PDGF signaling in cultured VSMCs and in restenosis. Arterioscler Thromb Vasc Biol 2006;26:2644-51. [CrossRef] 
DENEYSEL ÇALIŞMA - ÖZET

\section{Kurkumin'in PDGF ekspresyonu ve NF-kappa B üzerindeki etkisi: TNBS kolit modeli \\ Dr. Yüksel Altınel, ${ }^{1}$ Dr. Şenay Yalçın, ${ }^{2}$ Dr. Gülçin Ercan, ${ }^{1}$ Dr. Erkan Yavuz,, Dr. Candaş Erçetin, ${ }^{1}$ Dr. Osman Bilgin Gülçiçek, ${ }^{1}$ Dr. Atilla Çelik' Dr. Güven Özkaya, ${ }^{3}$ Dr. Hafize Uzun ${ }^{4}$}

'Bağcılar Eğitim ve Araştırma Hastanesi, Genel Cerrahi Kliniği, İstanbul
${ }^{2}$ Bağcılar Eğitim ve Araştırma Hastanesi, Patoloji Kliniği, İstanbul
${ }^{3}$ Uludağ Üniversitesi Tıp Fakültesi, Biyoistatistik Anabilim Dalı, Bursa
${ }^{4}$ Cerrahpaşa Üniversitesi Tıp Fakültesi, Biyokimya Anabilim Dalı, İstanbul

AMAÇ: Kurkumin, nükleer faktör kappa B’nin (NF-kappa B) güçlü bir inhibitörü olduğu bilinen antioksidan ve antienflamatuvar bir moleküldür. Kurkumin'in 2,4,6-trinitrobenzen sülfonik asit (TNBS) ile indüklenen kolit modeli üzerindeki etkisini araştırmayı amaçladık.

GEREÇ VE YÖNTEM: Anestezi altında kolit indüksiyonundan sonra, 42 sıçan altı gruba ayrıldı; kurkumin oral grup, kurkumin (20 mg/kg); mısır yağı oral grubu, mısır yağı $(20$ mg/kg) mide gavajı yoluyla, kurkumin rektal grubu, kurkumin; mısır yağı rektal grubu, mısır yağı. Kontrol grubuna I mL salin solüsyonu $(\% 0.9 \mathrm{NaCl})$ rektal yolla uygulandı. Sham grubunda sadece rektal kateterizasyon yapıldı. Yedi gün sonunda, histopatolojik inceleme ve MPO, MDA, NO, PDGF, IL-6, TNF-alfa, NF-kappa B için kan ve bağırsak doku örnekleri alındı.

BULGULAR: Makroskobik hasar skoru, kurkumin oral, mısır yağı oral ve salin gruplarında sham grubuna göre anlamlı olarak yüksek bulundu $(p<0.05)$. Gruplar arasındaki anlamlı fark, IL-6, NO, NF-kB, PDGF, TNF- $\alpha$, MDA, MPO intestinal dokunun biyokimyasal analizinde değerlendirildi $(p<0.05)$. Kurkumin oral, kurkumin rektal, sham, mısır yağı oral, mısır yağı rektal gruplarında NF-kB kan seviyeleri, salin rektal grubuna göre anlamlı olarak arttı $(p=0.00 I)$. Mısır yağı rektal ve kontrol grubunun NF-kB serum seviyeleri $(p \leq 0.00 \mathrm{I})$ sham grubundan düşük bulundu ( $p=0.0 \mathrm{I} 2)$.

TARTIŞMA: Kurkumin'in, NF-kB sinyal yolundaki duzenleyici etkisi muhtemelen iyileştirici özelliği ile gelecekteki çalışmalarda tek başına kolite karşı veya konvansiyonel anti-kolitik tedaviler de kombinasyon halinde düşünülmelidir.

Anahtar sözcükler: Antienflamatuvar; anti-oksidan; kolit; kurkumin; NF-kB.

Ulus Travma Acil Cerrahi Derg 2020;26(5): doi: 10.14744/tjtes.2019.45570 